\title{
HYDROTHERMAL SYNTHETIC RED BERYL FROM THE INSTITUTE OF CRYSTALlOGRAPHY, MOSCOW
}

\author{
By James E. Shigley, Shane F. McClure, Jo Ellen Cole, John I. Koivula, \\ Taijin Lu, Shane Elen, and Ludmila N. Demianets
}

\begin{abstract}
Hydrothermal synthetic red beryl has been produced for jewelry applications by the Institute of Crystallography and an affiliated company, Emcom Ltd., both in Moscow. Diagnostic identification features include: a tabular crystal morphology, chevron-like and subparallel or slightly wavy internal growth zoning, sharp absorption bands at approximately 530, 545, 560, 570, and $590 \mathrm{~nm}$ due to $\mathrm{Co}^{2+}$, waterrelated absorption bands between 4200 and $3200 \mathrm{~cm}^{-1}$ in the infrared spectrum, and the presence of Co and Ni peaks in EDXRF spectra.
\end{abstract}

ydrothermal synthetic red beryl from several sources in Russia has been sold commercially since the mid-1990s, as faceted stones up to several carats (see, e.g., figure 1). This article describes material produced by a private company (Emcom Ltd.) in affiliation with the Institute of Crystallography at the Russian Academy of Sciences in Moscow. The rarity, high value, and commercial interest in natural red beryl from Utah no doubt contributed initially to the goal of producing and marketing a synthetic counterpart. Today, limited demand for this color of synthetic beryl has curtailed production at the Institute of Crystallography, as well as by other producers (pers., comm., 2001: Walter Barshai-Pinky Trading Co., Los Angeles; Alex Grizenko-Russian Colored Stone Co., Golden, Colorado; Uriah Prichard-Morion Co., Brighton, Massachusetts). Nevertheless, synthetic red beryl continues to circulate in the marketplace.

\section{BACKGROUND}

Beryl Crystal Chemistry. Pure beryl $\left(\mathrm{Be}_{3} \mathrm{Al}_{2} \mathrm{Si}_{6} \mathrm{O}_{18}\right)$ is colorless. The presence of other elements gives rise to various colors $(\mathrm{Fe}, \mathrm{Cr}, \mathrm{V}$, and $\mathrm{Mn}$ for coloration in both natural and synthetic, plus $\mathrm{Ti}, \mathrm{Co}$, and $\mathrm{Ni}$ in synthetic beryls; Sinkankas, 1981; Fritsch and Rossman, 1987). These elements substitute for Al. Alkali elements (Li, $\mathrm{Na}, \mathrm{K}, \mathrm{Rb}, \mathrm{Cs}$ ) can also occur in minor amounts by substituting for Be and $\mathrm{Al}$ (Sinkankas, 1981; Aurisicchio et al., 1988; Deer et al., 1997, pp. 378-386); however, these elements do not affect beryl coloration. The beryl crystal structure contains two different sites along "open" channels that can incorporate water molecules (Schaller et al., 1962; Wood and Nassau, 1968; Schmetzer, 1989; Deer et al., 1997). These variations in transition metal, alkali element, and water contents in beryls cause differences in physical properties (such as refractive index, specific gravity, and color), as well as in visible and infrared absorption spectra.

Natural Red Beryl. Gem-quality red beryl occurs at a single locality in the Wah Wah Mountains of southern Utah (see, e.g., Flamini et al., 1983;

See end of article for About the Authors information and acknowledgments. Gems \& Gemology, Vol. 37, No. 1, pp. 42-55

(C) 2001 Gemological Institute of America 


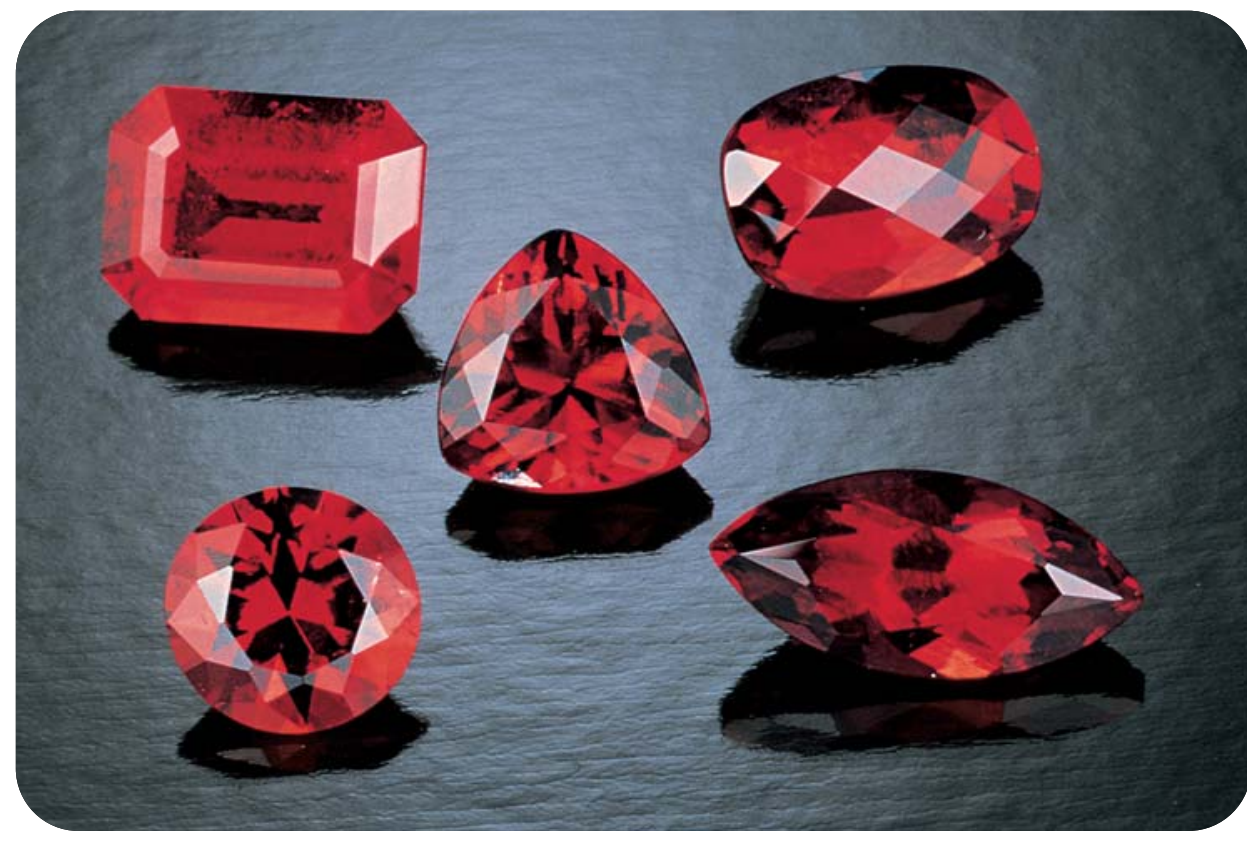

Figure 1. These faceted hydrothermal synthetic red beryls $(1.46-3.85 \mathrm{ct})$ are representative of material that has been produced at the Institute of Crystallography and Emcom Ltd. in Moscow. Photo (C) GIA and Tino Hammid.

Shigley and Foord, 1984). The crystals formed in fractures within devitrified rhyolite lava, probably as a result of the metasomatic reaction between a fluorine-rich gas or vapor phase and potassium feldspar (Aurisicchio et al., 1990; Henn and Becker, 1995). These crystals are often chemically zoned, which can result in an uneven coloration. This is seen as hexagonal orange-red core zones within purplish red rims when the crystals are viewed parallel to the c-axis, and as triangular or hourglassshaped orange-red core zones within the purplish red rims when the crystals are viewed perpendicular to the c-axis (Shigley and Foord, 1984, pp. 214-215, figures 7 and 8). The color of faceted material ranges from purplish red to red to orangered. Compared to most other beryls, red beryl is enriched in $\mathrm{Mn}, \mathrm{Fe}, \mathrm{Ti}, \mathrm{Rb}, \mathrm{Zn}$, and $\mathrm{Sn}$, and is depleted in $\mathrm{Na}, \mathrm{K}$, and $\mathrm{Mg}$. Red beryl is noted for its almost complete absence of water (Nassau and Wood, 1968; Aurisicchio et al., 1990), which is also unique among beryls that typically crystallize in hydrothermal geological environments.

Synthetic Beryls. Growth of synthetic emerald by the flux technique extends back 150 years, while hydrothermal growth of emerald began in the mid1960s (Nassau, 1976, 1980). Synthetic beryls with colors other than green have been grown by the hydrothermal method only during the past decade. Synthetic pink to red beryls have been reported by Emel'yanova et al. (1965), Taylor (1967), Solntsev et al. (1981), Lebedev et al. (1982, 1983), Platonov et al. (1989), Brown (1990, 1993), Troup et al. (1990), and
Fritsch et al. (1992). Henn and Milisenda (1999) described hydrothermal synthetic red beryl from an unstated source in Russia that has many gemological properties in common with the material described here. Although similar in overall appearance, the synthetic product differs in gemological properties from natural red beryl (for descriptions of the latter, see Nassau and Wood, 1968; Schmetzer et al., 1974; Miley, 1980; Flamini et al., 1983; Shigley and Foord, 1984; Aurisicchio et al., 1990; Hosaka et al., 1993; Harding, 1995).

\section{GROWTH CONDITIONS}

One of the authors (LD) grew the synthetic red beryl samples examined in this study. The crystals are grown by the so-called regeneration technique from a hydrothermal solution at temperatures of more than $600^{\circ} \mathrm{C}$ and pressures of more than 2000 bars (Demianets, 1996). Note that these conditions are similar to those reported for growing hydrothermal synthetic emeralds (Bukin et al., 1986, pp. 255-258; Schmetzer, 1988, pp. 157-162). Thin ( $\leq 1 \mathrm{~mm}$ thick) seed plates of either synthetic colorless beryl or synthetic emerald are used to initiate crystal growth. These seed plates are cut parallel to the dipyramid faces (general Miller form symbol \{hk $\overline{2 i} 1\}$ ).

To obtain the desired red to orange-red color, the manufacturers introduce Co and Mn simultaneously into the growth system (along with some $\mathrm{Fe}$ and alkaline elements). According to author LD, the typical content of transition metals in a synthetic red beryl crystal is on the order of $1 \mathrm{wt}$ \% Fe (1.28 


\section{SYNTHETIC RED BERYL CRYSTALS}

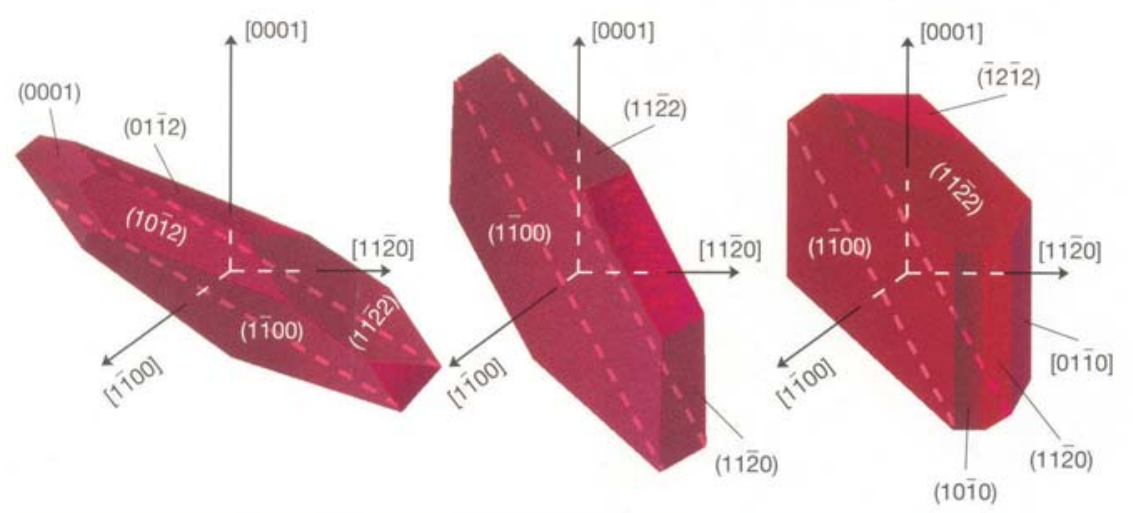

Figure 2. These idealized drawings of three synthetic red beryl crystals illustrate the morphology of this material, which is typical of that seen in other hydrothermally grown synthetic beryls. The crystal faces shown belong to one of the following forms: basal pinacoid \{0001\}, first-order prism $\{10 \overline{1} 0\}$, second-order prism $\{11 \overline{2} 0\}$,

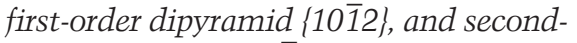
order dipyramid \{112̄2\}. Several minor faces that have been known to occur on actual crystals are not shown on these drawings. Zone axes are indicated by the Miller indices shown in brackets. The red dashed line in each drawing represents the seed plate. In the middle drawing, the surface with markings but no Miller index is not a true crystal face, but rather a growth surface that is parallel to the seed plate. wt. \% FeO), 0.12 wt. \% $\mathrm{Mn}(0.15$ wt. $\% \mathrm{MnO})$, and 0.18 wt. \% Co (0.23 wt. \% CoO).

The synthetic red beryl crystals are tabular and elongated parallel to the seed plate (figures 2 and 3). They exhibit first- and second-order prisms $\{10 \overline{1} 0\}$ and $\{11 \overline{2} 0\}$, first- and second-order dipyramids $\{10 \overline{1} 2\}$ and $\{11 \overline{2} 2\}$, and sometimes other faces (i.e., $\{11 \overline{2} 4\}$ and $\{0001\})$, depending on the orientation of the seed plate and on the differing growth rates for each crystal face. Researchers at the Institute of Crystallography confirmed the identity of these crystal faces by the single-crystal X-ray diffraction method, using a Rigaku diffractometer. The crystal faces are, for the most part, relatively flat. The surfaces oriented parallel to the seed plate have the highest growth rate and, therefore, exhibit various growth features (mainly growth hillocks and some hopper formations).

\section{MATERIALS AND METHODS}

We examined seven rough crystals and 27 faceted specimens of hydrothermal synthetic red beryl loaned by Worldwide Gem Marketing, the company that has sold this material for jewelry purposes on behalf of the Institute of Crystallography. The crystals ranged from 125.7 to $323.9 \mathrm{ct}$, and the faceted pieces ranged from 0.28 to 3.85 ct (all but three of these were $>1 \mathrm{ct})$. None of the faceted specimens exhibited any remnant of a seed plate.

We tested the rough and polished samples using standard gemological methods. Refractive indices were measured using a Duplex II refractometer. Specific gravity was calculated by the hydrostatic method from weight measurements by means of a Mettler AM100 electronic balance. We did not obtain S.G. measurements for the crystals, because of their large size and the presence of metal suspension wires that would distort the results. Fluorescence to ultraviolet radiation was documented in darkroom conditions with a standard long-wave (366 nm) and short-wave (254 nm) GIA Gem Instruments UV unit. Visible spectra were observed with Beck prism and Discan digital-scanning, diffraction-grating spectroscopes; a calcite dichroscope was used to observe pleochroism. Photomicrographs were taken with Nikon SMZ-U and SMZ-10 photomicroscopes.

Although the synthetic crystals varied in color (purplish red or orange-red), all of the faceted synthetic samples were relatively similar in color (red to orange-red); therefore, we documented representative samples of the latter as described below using advanced instrumentation. Two natural red beryls from Utah also were analyzed for comparison purposes: (1) a 1.95 ct purplish red crystal was polished on opposite sides in an orientation parallel to the caxis for use in recording visible and infrared spectra, and (2) a 1.50 ct purplish red crystal was used for qualitative chemical analysis.

Absorption spectra in the range $250-850 \mathrm{~nm}$ were recorded for three synthetic samples with a Hitachi U4001 spectrophotometer with a $2 \mathrm{~nm}$ slit width. To obtain polarized absorption spectra, we prepared an optically oriented flat plate from one of the orange-red synthetic crystals; we then used calcite polarizers to record spectra in orientations both parallel and perpendicular to the c-axis (the optic axis). Unpolarized absorption spectra also were recorded for two faceted synthetic samples.

We documented mid-infrared spectra for four 
Figure 3. The morphology of these synthetic red beryl crystals (125.7-323.9 ct) differs significantly from the hexagonal crystal form of natural red beryl (see inset, $2.1 \mathrm{~cm}$ tall; photo by leff Scovil). Photo (C) GIA and Tino Hammid.

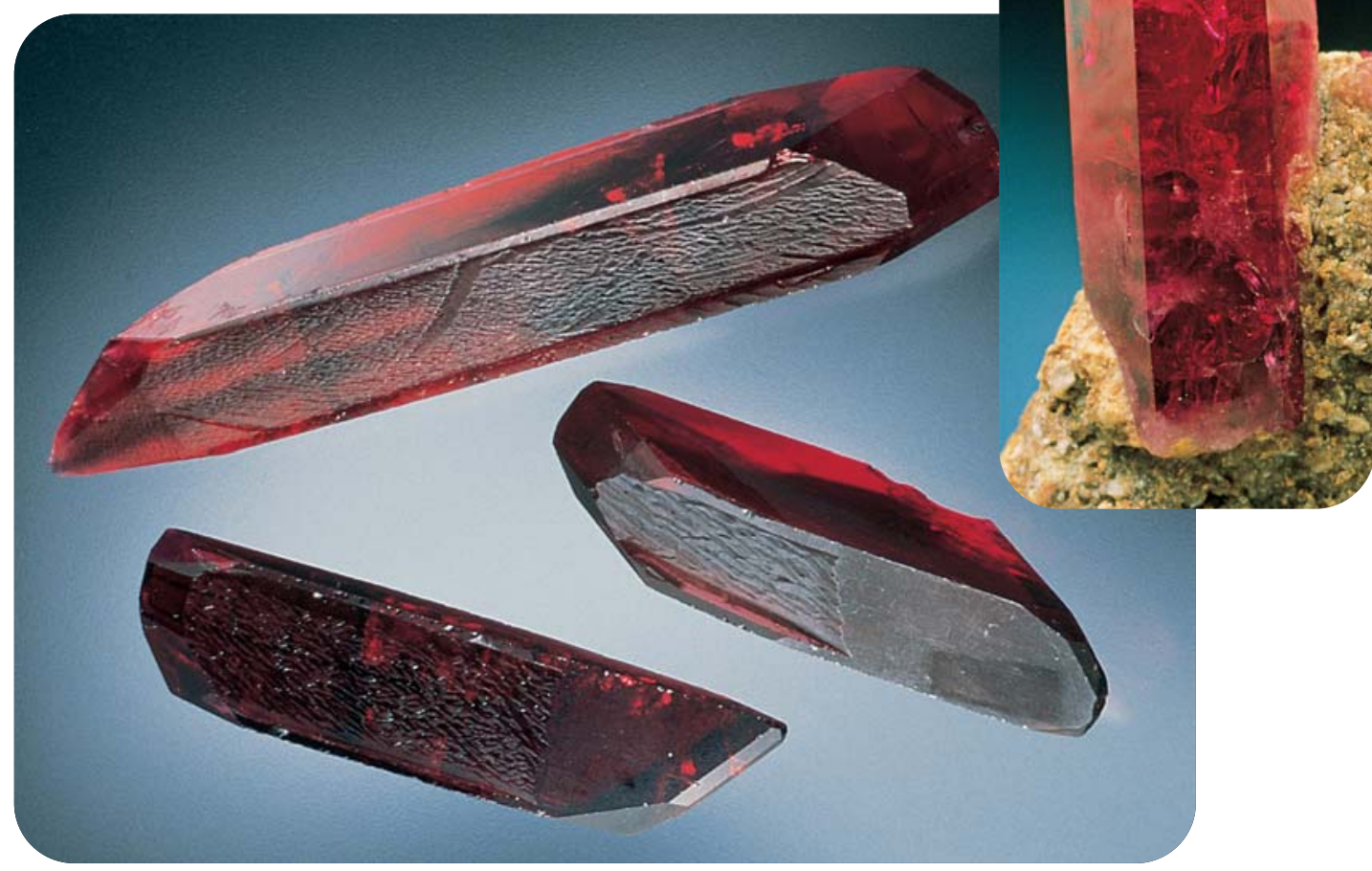

crystals and one faceted sample of synthetic red beryl with a Nicolet Magna 550 FTIR spectrometer, from 6600 to $400 \mathrm{~cm}^{-1}$, at a resolution of $4 \mathrm{~cm}^{-1}$. To compare our data with those published by Schmetzer and Kiefert (1990) for natural and synthetic beryls, we recorded an infrared transmission spectrum for fragments of one synthetic red beryl crystal. These fragments were embedded in powdered potassium bromide $(\mathrm{KBr})$ and then formed into a thin pellet for analysis. This is a standard procedure that is used to obtain an infrared spectrum from a small quantity of a material, to avoid exceeding the recording range of the detector of the infrared spectrometer. Such a sample produces an "average" infrared spectrum that is independent of crystal orientation.

The spectrum of a plate-like black inclusion seen in one orange-red synthetic crystal was recorded with a Renishaw 2000 Ramascope laser Raman microspectrometer over the range of 100 to $2000 \mathrm{~cm}^{-1}$.

Using two different sets of conditions to optimize the detection of certain elements, we performed qualitative EDXRF chemical analyses with a Tracor Spectrace 5000 instrument on one natural crystal, four faceted synthetic specimens, and three synthetic crystals. For low-atomic weight elements, the conditions were: $15 \mathrm{kV}$ tube voltage, $0.35 \mathrm{~mA}$ tube current, a vacuum atmosphere, no filter, and a 200 -second counting time. For detecting transition metals, we used: $35 \mathrm{kV}$ tube voltage, 0.30 or $0.35 \mathrm{~mA}$ tube current, ambient atmosphere, a thin filter, and a 200 -sec- ond counting time. While the EDXRF spectra we recorded represent a qualitative chemical analysis, we found that quantitative analyses using the same equipment and standards yielded an estimated detection limit of about $50 \mathrm{ppm}$ for the transition metals in rubies using the second set of analytical conditions.

Quantitative chemical analyses of three faceted synthetic red beryls were obtained with a JEOL 733 electron microprobe at the California Institute of Technology in Pasadena. The operating conditions were: $15 \mathrm{kV}$ beam voltage, $25 \mathrm{nA}$ beam current, 10 micron spot size, minerals or synthetic compounds as standards for the elements analyzed, and the CITZAF data correction procedure.

\section{RESULTS AND DISCUSSION}

Visual Characteristics of the Study Specimens. The seven synthetic crystals were similar in morphology and appearance, although they varied in color (five were purplish red, and two were orange-red). All of the 27 faceted samples were red to orange-red. Faceted natural red beryl can show a similar red to orange-red color range when the table is oriented perpendicular to the c-axis (long direction) of the crystal (Shigley and Foord, 1984). However, it is more often red to purplish red, since the table facet is commonly oriented parallel to the c-axis to maximize weight retention.

All seven synthetic crystals were tabular in shape, square in overall cross-section, and elongated in the 


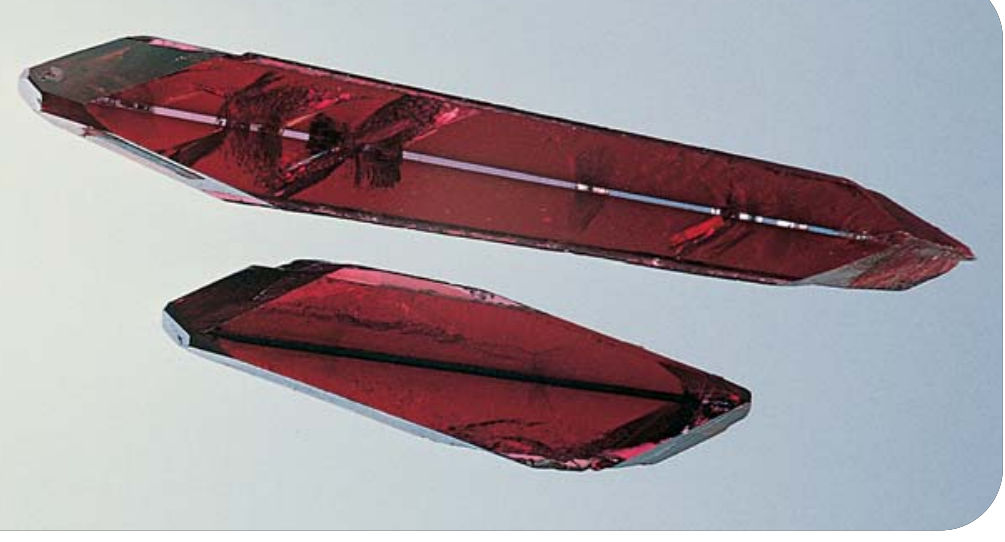

Figure 4. Hydrothermal synthetic red beryl from the Institute of Crystallography is grown from solutions onto thin seed plates of either colorless synthetic beryl (as in the top crystal, $323.9 \mathrm{ct}$ ) or synthetic emerald (bottom crystal, $125.7 \mathrm{ct}$ ). For the seven crystals we examined, the type of seed plate did not seem to influence the color, shape, or other features of the crystals. Photo (C) GIA and Tino Hammid.

direction of the seed plate. These plates varied from 0.7 to $1.0 \mathrm{~mm}$ in thickness, and extended the entire length of each crystal. Different beryl seed plates were observed: In the five purplish red crystals, two of the seed plates were colorless and three were green; in the two orange-red crystals, one was colorless and the other was green (see, e.g., figure 4). Angles between the c-axis and the seed plate were recorded for five of the crystals: four purplish red $-19^{\circ}, 17^{\circ}, 17^{\circ}$, and $15^{\circ}$; one orange-red $-17^{\circ}$. No obvious color zoning was seen in these crystals, except in one instance where there was a narrow band of lighter color along one outer edge. General comments on the appearance of the crystal faces (which were always present, except as noted below) are as follows:

- First-order prism \{1010\}: these faces, which cover the largest surface area, are relatively smooth and flat (except for very slight growth hillocks). However, on the prism faces along the sides of two crystals, rectangular-shaped depressions and other cavities were observed along the outer edge of the seed plate; these features result from postgrowth cleaning in acid.

- Second-order prism $\{11 \overline{2} 0\}:$ Relatively smooth and flat, these faces are smaller than the firstorder prisms.

- First-order dipyramid $\{10 \overline{1} 2\}:$ These faces are relatively smooth and flat.

- Second-order dipyramid $\{11 \overline{2} 2\}$ : These large faces are relatively smooth and flat.
- Basal pinacoid $\{0001\}$ : These faces are flat and very small, or are absent from some crystals.

- Second-order dipyramid $\{11 \overline{2} 4\}$ : Rarely present, these faces may form flat, very small areas.

There are also rough surfaces that are oriented parallel to the seed plate and perpendicular to the direction of fastest crystal growth. These are not true crystal faces. They exhibit characteristic growth hillocks that are related to the internal chevron-like growth zoning. Similar faces and surface features have been observed on hydrothermal synthetic emerald crystals (Schmetzer, 1988; Sosso and Piacenza, 1995; Schmetzer et al., 1997).

Gemological Properties. The gemological properties of the faceted synthetic red beryls are described below and summarized in table 1 .

Refractive Index. Of the 26 faceted samples on which R.I.'s were taken, 24 exhibited values of $1.569-1.573\left(\mathrm{n}_{\varepsilon}\right)$ and $1.576-1.580\left(\mathrm{n}_{\omega}\right)$, with a birefringence of $0.006-0.008$. One sample had R.I. values of 1.561 and 1.567 , and the other showed 1.582 and 1.588 (both with a birefringence of 0.005); there were no obvious features that might cause these discrepancies. Henn and Milisenda (1999) reported very similar R.I. values of $1.570-1.572$ and 1.578-1.580 (birefringence of 0.008) for the synthetic red beryl samples they examined.

The two R.I. values for natural beryls of all kinds generally range from 1.565 to 1.599 and 1.569 to 1.610 (Deer et al., 1997, p. 372). Sinkankas (1981) cited slightly lower ranges of 1.563-1.597 and 1.567-1.602. Higher concentrations of the alkali elements $(\mathrm{Li}, \mathrm{Na}$, $\mathrm{K}, \mathrm{Cs}$ ) cause an increase in R.I. values in beryls (Cerny' and Hawthorne, 1976; Schmetzer, 1988, p. 149; Deer et al., 1997). Published chemical analyses for 29 beryls of various colors (except red; all natural beryls except for one synthetic emerald) indicate $\mathrm{Na}_{2} \mathrm{O}$ values of $0.10-2.50$ wt. \% and $\mathrm{K}_{2} \mathrm{O}$ values of $0-0.65$ wt. \% (Deer et al., 1997, pp. 380-385). In published analyses of natural red beryl, values for these oxides fall in the ranges of 0.03-0.39 wt. $\% \mathrm{Na}_{2} \mathrm{O}$ and $0.09-0.29$ wt. $\% \mathrm{~K}_{2} \mathrm{O}_{\text {; }}$ in the hydrothermal synthetic red beryl examined here, the same two oxides varied from 0.06 to $0.12 \mathrm{wt} . \%$ and $0.02-0.04 \mathrm{wt} . \%$, respectively (see table 2). The relatively low concentrations of $\mathrm{Na}$ and $\mathrm{K}$ in both the natural and synthetic red beryls we studied are consistent with their low R.I. values. However, the influence of alkali element concentrations on lowering R.I. 
TABLE 1. Properties of hydrothermal synthetic and natural red beryl.

\begin{tabular}{|c|c|c|}
\hline Property & Synthetic & Natural \\
\hline Source & Institute of Crystallography / Emcom Ltd., Moscow & Wah Wah Mountains, Utah \\
\hline References & This study (c.f., Henn and Milisenda, 1999) & This study; Shigley and Foord (1984) \\
\hline Color & Red to orange-red & Purplish red to red to orange-red \\
\hline Crystal morphology & $\begin{array}{l}\text { Tabular, square cross-section, elongated in the } \\
\text { direction of the seed plate, which is oriented } 15^{\circ}-19^{\circ} \\
\text { to the c-axis }\end{array}$ & $\begin{array}{l}\text { Prismatic, hexagonal cross-section, elongated parallel } \\
\text { to the c-axis }\end{array}$ \\
\hline $\begin{array}{l}\text { Crystal forms } \\
\text { (and relative occurrence) }\end{array}$ & $\begin{array}{l}\{10 \overline{1} 0\},\{11 \overline{2} 0\},\{10 \overline{1} 2\},\{11 \overline{2} 2\}-\text { common } \\
\{0001\},\{11 \overline{2} 4\} \text {-rare }\end{array}$ & $\begin{array}{l}\{0001\} \text { and }\{10 \overline{1} 0\} \text {-common } \\
\{11 \overline{2} 1\} \text { and }\{11 \overline{2} 2\} \text {-less common } \\
\{11 \overline{2} 0\} \text {-rare } \\
\{10 \overline{1} 1\} \text {-very rare }\end{array}$ \\
\hline Features on crystal faces & $\begin{array}{l}\text { Prism }\{10 \overline{1} 0\},\{11 \overline{2} 0\} \text {-usually smooth } \\
\text { Dipyramid }\{10 \overline{1} 2\},\{11 \overline{2} 2\} \text {-usually smooth }\end{array}$ & $\begin{array}{l}\text { Prism }\{10 \overline{1} 0\} \text { - usually smooth } \\
\text { Dipyramid }\{11 \overline{2} 2\}-\text { smooth } \\
\text { Basal pinacoid }\{0001\} \text { - usually flat }\end{array}$ \\
\hline $\begin{array}{l}\mathrm{n}_{\varepsilon} \\
\mathrm{n}_{\omega}\end{array}$ & $\begin{array}{l}1.569-1.573 \\
1.576-1.580\end{array}$ & $\begin{array}{l}1.564-1.569 \\
1.568-1.572\end{array}$ \\
\hline Birefringence & $0.006-0.008$ & $0.006-0.008$ \\
\hline Specific gravity & $2.67-2.70$ & $2.66-2.70$ \\
\hline $\begin{array}{l}\text { Pleochroism } \\
\text { Parallel to c-axis } \\
\text { Perpendicular to c-axis }\end{array}$ & $\begin{array}{l}\text { Purplish red } \\
\text { Orange-red to orange-brown }\end{array}$ & $\begin{array}{l}\text { Purplish red } \\
\text { Red to orange-red }\end{array}$ \\
\hline UV fluorescence & Inert & Inert \\
\hline Color distribution & $\begin{array}{l}\text { Even, except for some brown banding along } \\
\text { growth zones }\end{array}$ & $\begin{array}{l}\text { Sometimes even, often zoned with a triangular or hour- } \\
\text { glass shape (when viewed perpendicular to the c-axis) }\end{array}$ \\
\hline Internal growth zoning & $\begin{array}{l}\text { Chevron-like and subparallel or slightly wavy patterns } \\
\text { (causing a roiled optical effect) }\end{array}$ & None \\
\hline \multicolumn{3}{|l|}{ Inclusions } \\
\hline Fluid inclusions & $\begin{array}{l}\text { Occasional tiny single- or two-phase inclusions (liquid, } \\
\text { or liquid plus gas) along partially healed fractures } \\
\text { (rare in faceted material) }\end{array}$ & $\begin{array}{l}\text { Numerous single- or two-phase inclusions (liquid, or } \\
\text { liquid plus gas) often along planar or curved fractures } \\
\text { or forming "fingerprint" patterns }\end{array}$ \\
\hline Solid inclusions & $\begin{array}{l}\text { Hematite platelets, tiny triangular inclusions with a } \\
\text { dendritic appearance (unidentified), and "nailhead" spi- } \\
\text { cules (both rare in the faceted material examined here) }\end{array}$ & $\begin{array}{l}\text { Tiny grains or crystals of quartz, bixbyite, feldspar, } \\
\text { and/or hematite }\end{array}$ \\
\hline Other features & Fractures, seed plate, metal wires (in crystals only) & Fractures, sometimes with brown (iron oxide) staining \\
\hline Distinctive trace elements & $\mathrm{Co}$ and $\mathrm{Ni}$ & Cs, Sn, and Zn \\
\hline $\begin{array}{l}\text { Visible spectra } \\
\text { (spectrophotometer) }\end{array}$ & $\begin{array}{l}\text { Weak bands at } 370 \text { and } 410 \mathrm{~nm} \text {; broad absorption } \\
\text { between } 400 \text { and } 470 \mathrm{~nm} \text {; broad absorption between } \\
480 \text { and } 600 \text { with superimposed bands at approx- } \\
\text { imately } 530,545,560,570 \text {, and } 585 \mathrm{~nm}\end{array}$ & $\begin{array}{l}\text { Absorption below } 400 \mathrm{~nm} \text {; weak bands at } 370,430 \text {, and } \\
485 \mathrm{~nm} \text {; and broad absorption between } 450 \text { and } 600 \mathrm{~nm} \\
\text { (centered at approximately } 560 \mathrm{~nm} \text { ) }\end{array}$ \\
\hline Infrared spectra & $\begin{array}{l}\text { Presence of strong absorption between } 4200 \text { and } \\
3200 \mathrm{~cm}^{-1} \text { (due to water) }\end{array}$ & $\begin{array}{l}\text { Absence of absorption between } 4200 \text { and } 3200 \mathrm{~cm}^{-1} \\
\text { (lack of water) }\end{array}$ \\
\hline
\end{tabular}

values is probably offset somewhat by the presence of transition metals (e.g., $\mathrm{Mn}, \mathrm{Fe}, \mathrm{Ti}$ ) in red beryl. Schmetzer (1988) discussed the opposing effects of alkali elements and transition metals on the optical properties of synthetic emeralds.

Although not an essential component, water is present in most natural beryls in amounts up to 2.7 wt. \% $\mathrm{H}_{2} \mathrm{O}$ (Deer et al., 1997). Nassau and Wood (1968) cited a range of 0.3-3.0 wt.\% $\mathrm{H}_{2} \mathrm{O}$ from published analyses of beryls. Černy' and Hawthorne (1976) discussed how increasing amounts of water in beryls are accompanied by increasing R.I. values. Nassau and Wood (1968) reported that water is near- ly absent (i.e., they could not detect it using infrared spectroscopy) in natural red beryl from Utah, due to the geologic conditions of its formation. Shigley and Foord (1984) reported only $0.36 \mathrm{wt} . \% \mathrm{H}_{2} \mathrm{O}$ (obtained by a microcoulometric analytical technique) for a single natural red beryl. Again, this very low water content may contribute to the low R.I. values. The synthetic red beryls examined for this study were not analyzed quantitatively for water, but they contained sufficient water for it to be readily detectable by routine mid-infrared spectroscopy techniques, as is typical of any hydrothermally grown synthetic beryl (see Schmetzer and Kiefert, 1990). 
TABLE 2. Partial chemical analyses of hydrothermal synthetic and natural red beryl by electron microprobe. ${ }^{a}$

\begin{tabular}{|c|c|c|c|c|c|c|c|c|c|}
\hline \multirow{2}{*}{ Oxide (wt.\%) } & \multicolumn{4}{|c|}{ Hydrothermal synthetic } & \multicolumn{5}{|c|}{ Natural } \\
\hline & This study ${ }^{b}$ & This study ${ }^{b}$ & This study ${ }^{b}$ & $\begin{array}{l}\text { Henn and Mili- } \\
\text { senda }(1999)^{c}\end{array}$ & $\begin{array}{l}\text { Flamini et al. } \\
\quad(1983)^{d}\end{array}$ & $\begin{array}{c}\text { Shigley and Foord } \\
(1984)^{\mathrm{e}}\end{array}$ & $\begin{array}{l}\text { Aurisicchio } \\
\text { et al. }(1990)^{\dagger}\end{array}$ & $\begin{array}{l}\text { Aurisicchio } \\
\text { et al. (1990) }\end{array}$ & Harding (1995) ${ }^{\mathrm{h}}$ \\
\hline $\mathrm{SiO}_{2}$ & 65.37 & 65.54 & 65.79 & 66.08 & 64.71 & 66.80 & 66.18 & 64.84 & 67.17 \\
\hline $\mathrm{TiO}_{2}$ & 0.02 & 0.01 & n.d. & 0.05 & 0.28 & 0.40 & 0.25 & 0.52 & 0.29 \\
\hline $\mathrm{Al}_{2} \mathrm{O}_{3}$ & 16.79 & 16.99 & 17.01 & 16.96 & 17.75 & 17.60 & 16.51 & 18.14 & 16.75 \\
\hline $\mathrm{Cr}_{2} \mathrm{O}_{3}$ & 0.03 & 0.04 & 0.03 & 0.02 & n.r. & n.r. & n.r. & n.r. & n.r. \\
\hline $\mathrm{FeO}$ & 1.48 & 1.47 & 1.32 & 1.62 & 1.46 & 1.80 & 2.63 & 1.96 & 2.81 \\
\hline $\mathrm{MnO}$ & 0.03 & n.d. & 0.01 & 0.18 & 0.18 & 0.30 & 0.73 & 0.27 & 0.82 \\
\hline $\mathrm{CoO}$ & 0.30 & 0.26 & 0.30 & 0.31 & n.r. & n.r. & n.r. & n.r. & n.r. \\
\hline $\mathrm{MgO}$ & 0.12 & 0.15 & 0.15 & 0.03 & 0.40 & 0.10 & n.r. & 0.27 & n.r. \\
\hline $\mathrm{CaO}$ & n.a. & n.a. & n.a. & n.r. & n.r. & n.r. & n.r. & n.r. & 0.13 \\
\hline $\mathrm{Na}_{2} \mathrm{O}$ & 0.06 & 0.12 & 0.08 & 0.06 & 0.39 & 0.03 & n.d. & 0.20 & n.r. \\
\hline $\mathrm{K}_{2} \mathrm{O}$ & 0.03 & 0.04 & 0.02 & 0.01 & 0.09 & 0.10 & n.d. & 0.29 & 0.10 \\
\hline $\mathrm{Cs}_{2} \mathrm{O}$ & n.a. & n.a. & n.a. & n.r. & 0.21 & 0.25 & n.r. & 0.56 & n.r. \\
\hline $\mathrm{SnO}_{2}$ & n.a. & n.a. & n.a. & n.r. & n.r. & 0.02 & n.r. & n.r. & n.r. \\
\hline $\mathrm{ZnO}$ & n.a. & n.a. & п.а. & n.r. & n.r. & 0.08 & n.d. & n.r. & n.r. \\
\hline Total $^{\mathrm{a}}$ & 84.23 & 84.62 & 84.71 & 85.32 & 85.47 & 87.48 & 86.30 & 87.05 & 88.07 \\
\hline \multicolumn{10}{|c|}{ 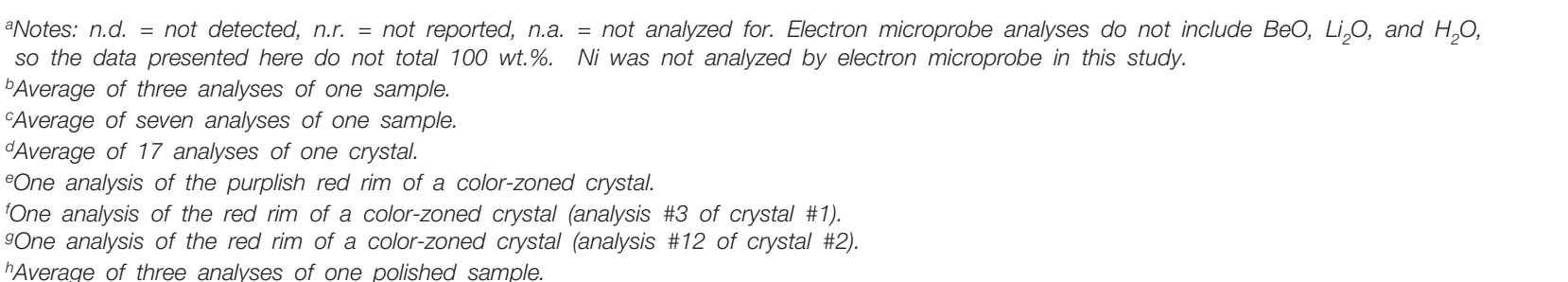 } \\
\hline
\end{tabular}

Specific Gravity. All 27 faceted synthetic red beryls had S.G. values in the range 2.67-2.70. Henn and Milisenda (1999) reported S.G. values of 2.63-2.65 for their study samples. For synthetic emeralds of all kinds colored by Cr or V, Sinkankas (1981) reported a maximum S.G. range of 2.65-2.71. Taylor (1967) reported S.G. values of 2.67-2.68 for pink Co-colored synthetic beryl, and Brown (1993) indicated 2.685 for a Ti-doped hydrothermal synthetic beryl. For comparison, natural beryls of all kinds have a maximum S.G. range of 2.63-2.92 (Sinkankas, 1981; Deer et al., 1997). Schmetzer (1988) discussed how increasing concentrations of alkali elements and transition metals in beryls are accompanied by increasing S.G. values. As mentioned above, the synthetic red beryl examined here is deficient in alkali elements, but it contains greater amounts of the transition metals relative to most natural beryls.

Polariscope Reaction. Each of the 27 faceted synthetic red beryls exhibited typical double refraction with a uniaxial optic figure. The orientation of the optic axis varied from nearly parallel to nearly perpendicular to the table facet; however, most were oriented with the c-axis at no more than about $20^{\circ}$ from the plane of the table. These variations result from the tabular crystal shape, coupled with the desire to maximize weight retention during faceting without including portions of the seed plate.

Pleochroism. When viewed with a dichroscope, all 27 faceted samples of synthetic red beryl exhibited moderate to very strong, purplish red $\left(\mathrm{n}_{\mathrm{e}}\right)$ and orange-red to orange-brown $\left(\mathrm{n}_{\mathrm{w}}\right)$ dichroism (figure 5).

Absorption Features Seen with a Desk-Model Spectroscope. The spectra of each of the faceted synthetic red beryls displayed the same general pattern of absorption features: a broad region of absorption below $400 \mathrm{~nm}$, a broad region of absorption from about 420 to $470 \mathrm{~nm}$, a region of absorption from about 400 to $600 \mathrm{~nm}$ containing a narrow (slightly diffuse) absorption band of moderate intensity centered at about 530 $\mathrm{nm}$, two strong sharp bands at about 545 and $560 \mathrm{~nm}$, and two weak sharp bands at about 570 and $590 \mathrm{~nm}$. 


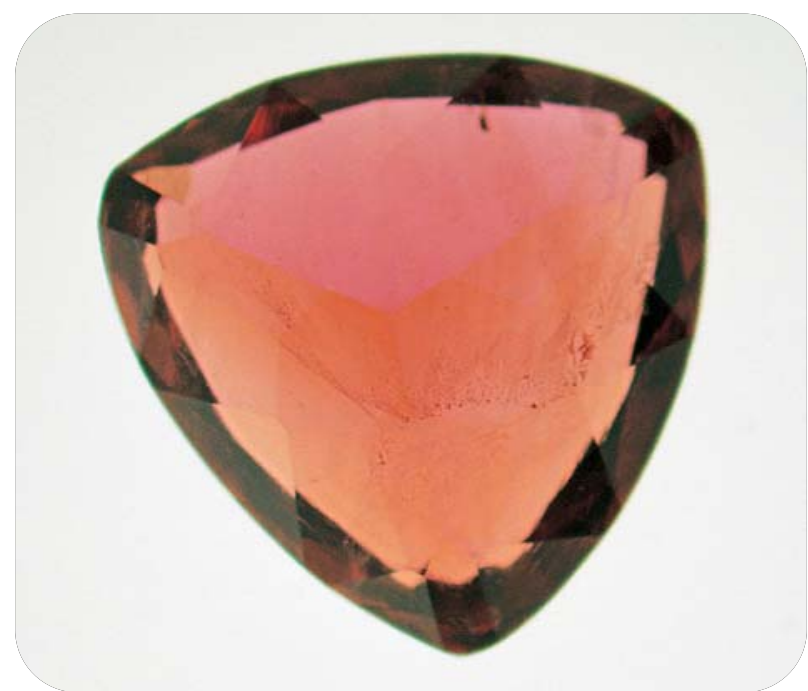

Figure 5. The synthetic red beryls studied showed moderate to very strong dichroism. When viewed table-down, this $0.75 \mathrm{ct}$ triangle shape displayed purplish red and orange-brown pleochroic colors. Photomicrograph by James Shigley; magnified $3 \times$.

This pattern is quite different from the spectrum of the natural red beryl we examined, which showed an intense region of absorption below about $450 \mathrm{~nm}$ and a broad absorption between about 540 and $580 \mathrm{~nm}$. Thus, the presence of several diffuse-to-sharp absorption bands between 530 and $590 \mathrm{~nm}$ (due to $\mathrm{Co}^{2+}$ ) is distinctive of this hydrothermal synthetic red beryl.
Internal Characteristics. Examination of the crystals and faceted samples of synthetic red beryl with a binocular microscope revealed the following features:

1. Prominent internal growth zoning (figure 6) was oriented at an oblique angle to the seed plate. According to Schmetzer (1988), this kind of zoning in hydrothermal synthetic beryls arises from the growth of a number of subparallel "crystallites" at an oblique angle to the seed plate. Their intersection produces chevron-like microstructures, which are best seen when the sample is viewed perpendicular to the plane of the seed plate. He noted that this internal growth zoning also gives rise to a roiled optical effect.

2. A subparallel or slightly wavy pattern (sometimes brownish) was best seen when the samples were examined parallel to the seed plate direction (figure 7); it is related to the internal growth zoning mentioned above. When the samples were viewed with crossed polarizers, a strain pattern that mimics this growth zoning was evident (figure 8).

3. Remnants of the metal wire used to suspend the crystals during growth may be present at one or both ends of the crystals; these were not seen in the faceted samples.

4. Occasional small, partially healed fractures-usually planar or curved in shape, but sometimes in more complicated patterns - contained tiny liquid

Figure 6. The most distinctive visual feature of the hydrothermal synthetic red beryls examined was chevron-like internal growth zoning. From observations in the original crystals, we know that this zoning is oriented along the direction of crystal growth at a high, oblique angle to the plane of the seed plate. Photomicrographs by James Shigley; left-magnified 3x, right-magnified 9x.
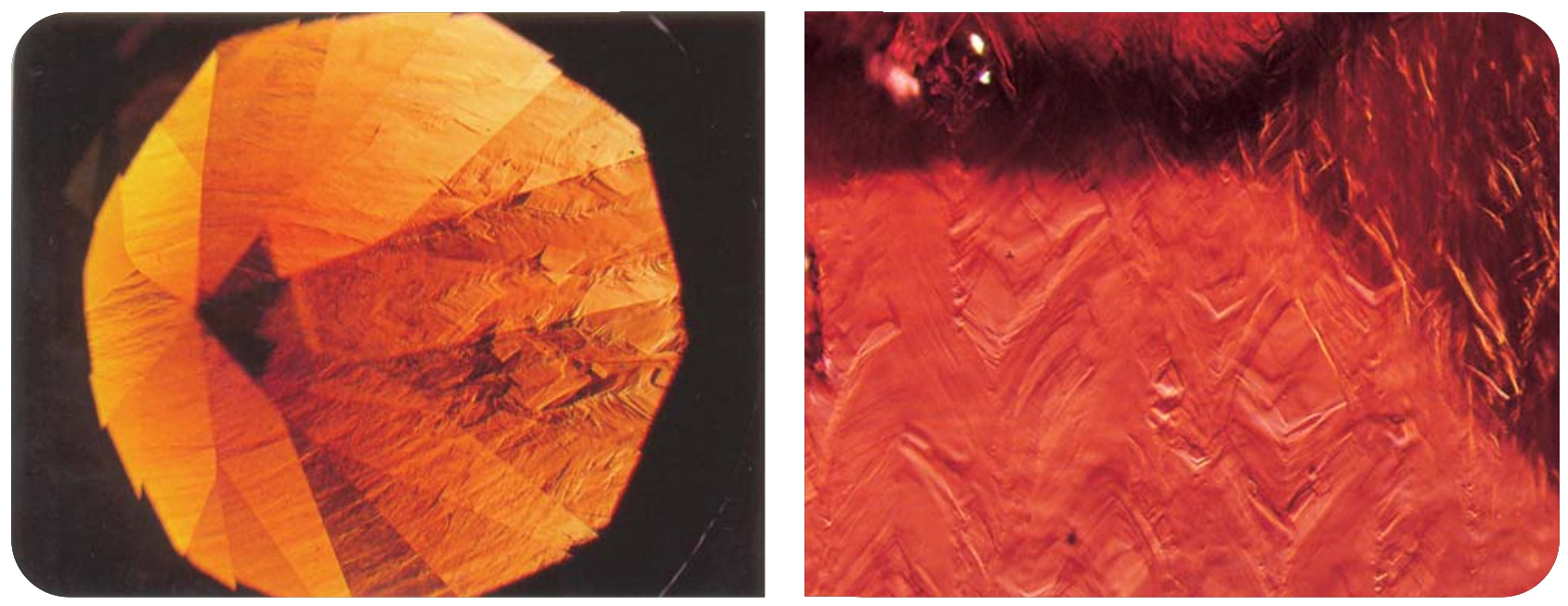

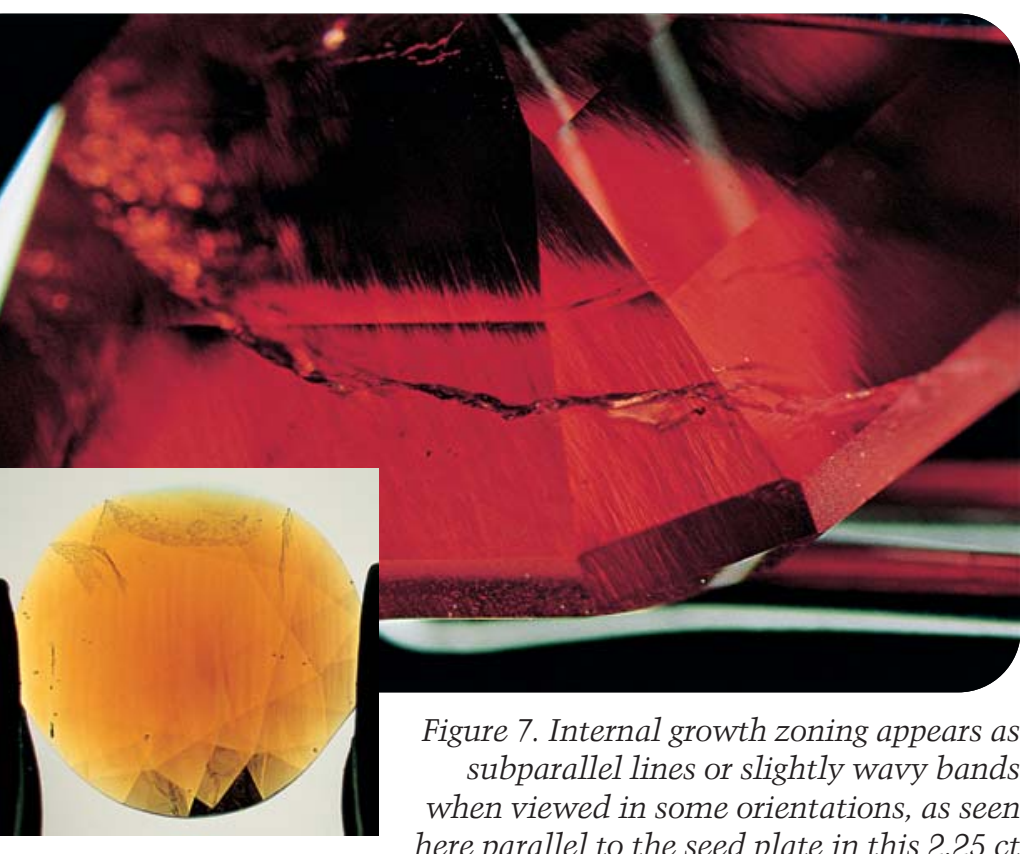

Figure 7. Internal growth zoning appears as subparallel lines or slightly wavy bands when viewed in some orientations, as seen here parallel to the seed plate in this $2.25 \mathrm{ct}$ faceted synthetic red beryl. (Photomicrograph by Shane Elen; magnified 4x.) When immersed in water, the subparallel or slightly wavy growth banding in some of the faceted specimens had a slightly brownish appearance (see inset); several partially healed fractures are also visible. (Photomicrograph by James Shigley; magnified 2×.)

or liquid-and-gas inclusions (figure 9). In general, these fractures were absent from the faceted material, presumably because they were excluded during fashioning.

5. Occasional isolated liquid-and-gas inclusions (figure 10) and rare solid inclusions were seen in the

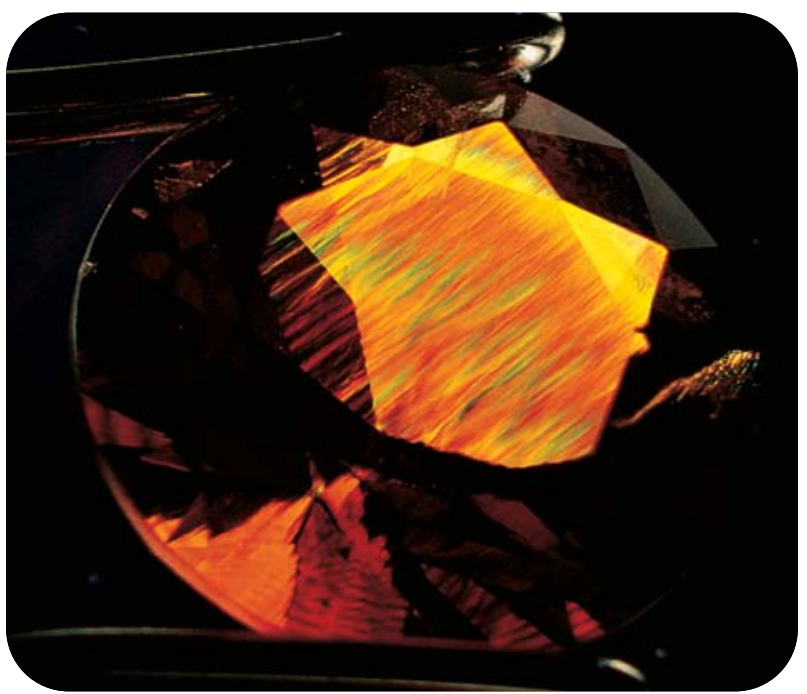

Figure 8. When this 2.59 ct faceted synthetic red beryl was viewed with crossed polarizers, the strain pattern was seen to follow the banded growth zoning. Photomicrograph by Shane Elen.

synthetic crystals. A few tiny triangular inclusions were noted along the edge of the seed plate in several crystals, but they could not be identified because of their size, orientation, and location (figure 11). A prominent opaque black platelet in one of the synthetic red beryl crystals was identified by Raman analysis as hematite (figure 12).

6. Occasional "nailhead" spicules were present near the seed plate (figure 13). Some were hollow and others contained two phases (liquid and gas); they were "capped" by a colorless or a colored solid inclusion that, again, we were unable to identify by Raman analysis because of their nature and location.

Figure 9. Some synthetic red beryl samples contained small, partially healed fractures composed of numerous tiny liquid or liquid-and-gas inclusions along lines or forming small "fingerprint" patterns. Although often planar, some partially healed fractures displayed curved shapes. Photomicrographs by James Shigley; magnified 8x (left) and 14x (right).
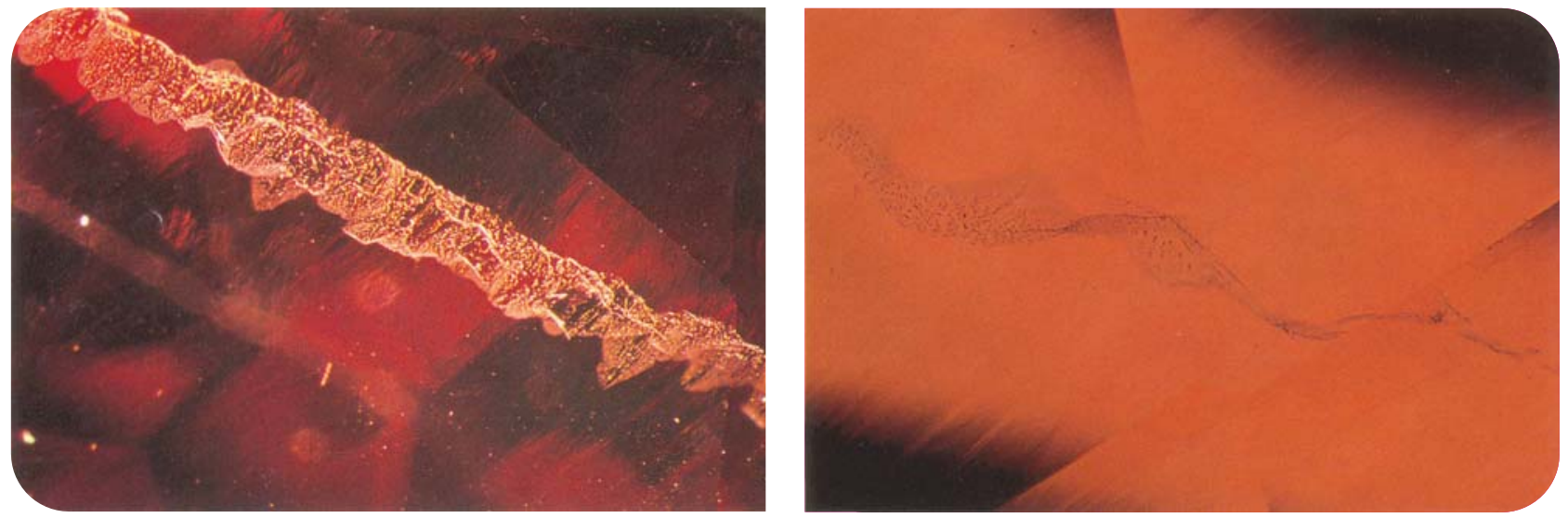


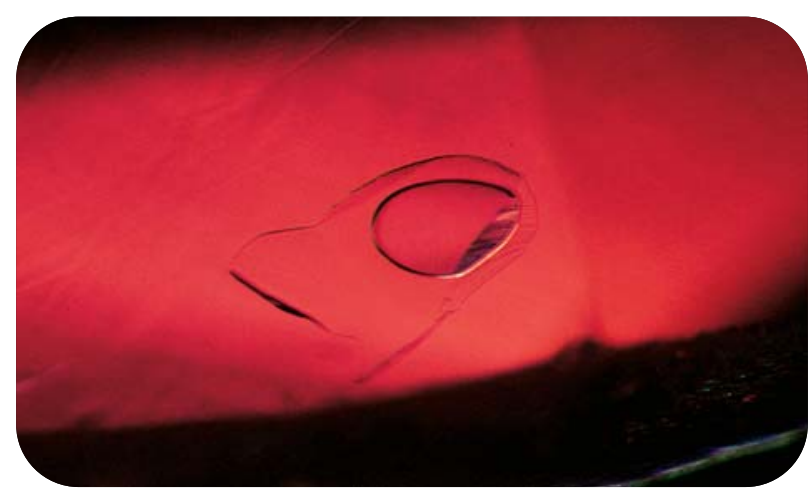

Figure 10. Isolated two-phase fluid (liquid and gas) inclusions were seen in several of the synthetic red beryl crystals, but less frequently in the faceted samples. Photomicrograph by John I. Koivula; magnified 25x.

Although none of the faceted samples we examined contained remnants of the seed plate, the metal suspension wire, or any large fractures, such features have been reported in hydrothermal synthetic emeralds and could be present in other faceted samples of hydrothermal synthetic red beryl.

It is important to note that almost all of the inclusions that have been reported in natural red beryl (see, e.g., Shigley and Foord, 1984; table 1) are quite different from those seen in its synthetic counterpart.

Chemical Composition. The electron microprobe analyses in table 2 are of synthetic and natural red beryls from this study and elsewhere. In addition to the elements shown in this table, we detected the presence of $\mathrm{Cu}, \mathrm{Ni}$, and $\mathrm{Rb}$ in the synthetic materi$\mathrm{al}$, and $\mathrm{Cu}, \mathrm{Ga}$, and $\mathrm{Rb}$ in a natural red beryl using EDXRF (figure 14). The most diagnostic elements for identifying synthetic red beryl are Co and Ni. Neither of these elements was detected by the highly sensitive emission spectrography technique in a natural red beryl (Shigley and Foord, 1984, p. 216), nor have they been reported elsewhere for the natural material. Using EDXRF, we also found $\mathrm{Cr}$ in a synthetic red beryl, but minute amounts of this element have been detected in natural red beryl (Shigley and Foord, 1984).

Absorption Spectroscopy. Polarized visible spectra for an orange-red synthetic and a purplish red natural beryl are presented in figure 15. Several features are shown in the synthetic red beryl spectrum polarized parallel to the c-axis (figure 15A; attributed causes shown in parentheses, after Solntsev et al., 1981):

1. Weak bands at about $370 \mathrm{~nm}\left(\mathrm{Fe}^{3+}\right)$ and $410 \mathrm{~nm}\left(\mathrm{Ni}^{3+}\right)$

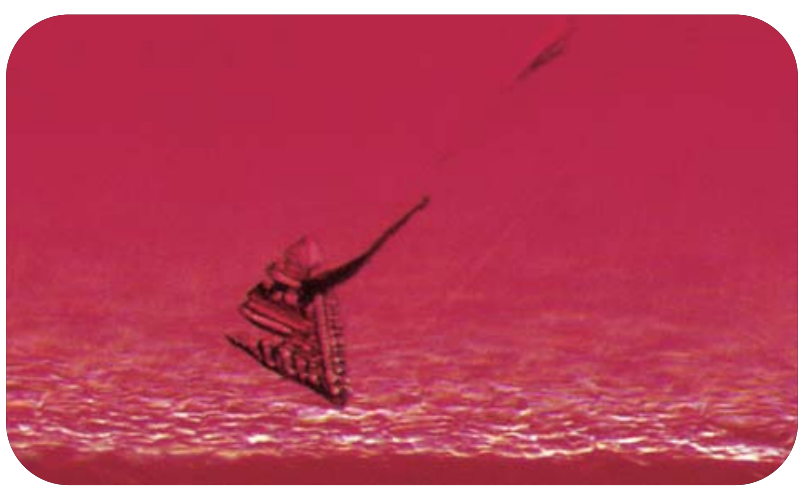

Figure 11. A few triangular-shaped inclusions were seen in several of the synthetic red beryl crystals along seed-plate boundaries. Because the seed plate and adjacent areas are removed during faceting, such inclusions are unlikely to occur in cut stones; they were not present in the faceted specimens examined for this study. Photomicrograph by James Shigley; magnified 20x.

2. A strong broad absorption region between 400 and $470 \mathrm{~nm}$ (maximum at about $450 \mathrm{~nm}$, due to $\mathrm{Co}^{2+}$ )

3. A strong broad absorption region from 480 to $600 \mathrm{~nm}$ (maximum at about $560 \mathrm{~nm}$ ), with a weak band at about $525 \mathrm{~nm}$ and superimposed sharp peaks at 545, 560, 570, and $585 \mathrm{~nm}$ (all due to $\left.\mathrm{Co}^{2+}\right)$

The two regions of strong absorption /centered at about 450 and $560 \mathrm{~nm}$ ) are of approximately equal intensity in the spectrum in figure 15A. In the spectrum polarized perpendicular to the c-axis (figure $15 \mathrm{~B}$ ), the absorption region centered at $450 \mathrm{~nm}$ is much more intense. These spectra are comparable to those for synthetic beryls published by Emel'yanova

Figure 12. This opaque black inclusion was identified as hematite by Raman analysis. Photomicrograph by James Shigley; magnified 15x.

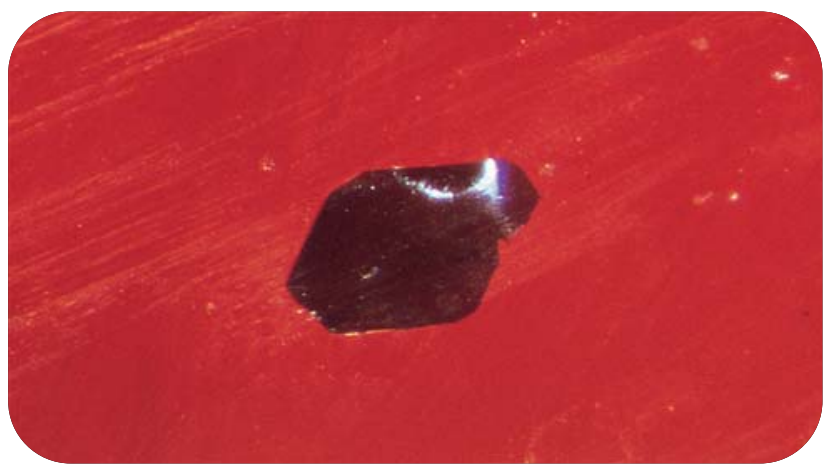



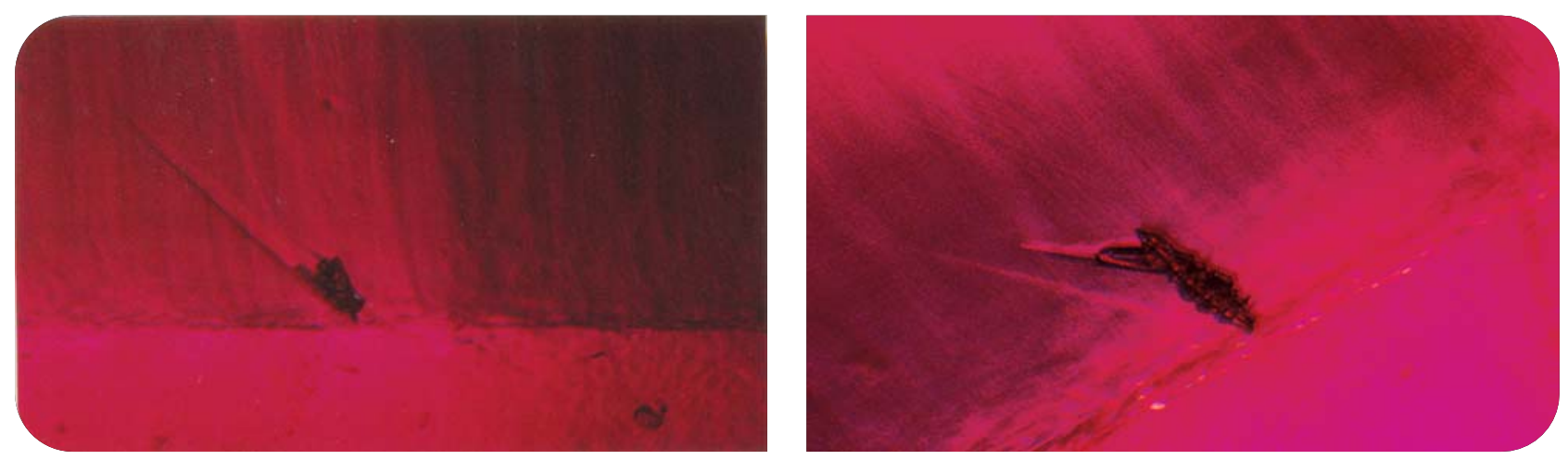

Figure 13. "Nailhead" spicules were occasionally observed in the crystals, near the seed plate. They are formed by an unknown solid phase and an associated hollow tube filled with a liquid (left), and sometimes with a gas bubble (right). Photomicrographs by John I. Koivula; magnified 40x.

et al. (1965), Lebedev et al. (1982, 1983), and Henn and Milisenda (1999, figure 2; except that, in their spectrum polarized parallel to the c-axis, the absorption region centered at $560 \mathrm{~nm}$ is more intense than the one centered at $450 \mathrm{~nm}$ ).

For the natural red beryl, the spectrum polarized parallel to the c-axis (figure 15C) exhibits the fol- lowing features (for comparison, see Solntsev et al., 1981; Shigley and Foord, 1984):

1. Increasing absorption below $400 \mathrm{~nm}\left(\mathrm{Fe}^{3+}\right)$

2. A weak peak at about $430 \mathrm{~nm}\left(\mathrm{Fe}^{3+}\right)$

3. A broad intense region of absorption from 450 to $600 \mathrm{~nm}$ (centered at about $560 \mathrm{~nm} ; \mathrm{Mn}^{3+}$ )

Figure 14. EDXRF spectra of an orange-red hydrothermal synthetic red beryl ( $A$ and $B$ ) and a natural purplish red beryl crystal from Utah (C and D) show notable differences in chemical composition.

Analytical conditions were optimized to detect low-atomic-weight elements ( $A$ and $C$ ) and transition metals ( $B$ and $D$ ). Peaks resulting from instrumental artifacts are not labeled, and should be ignored. The distinctive elements in the synthetic red beryl are Co and Ni.

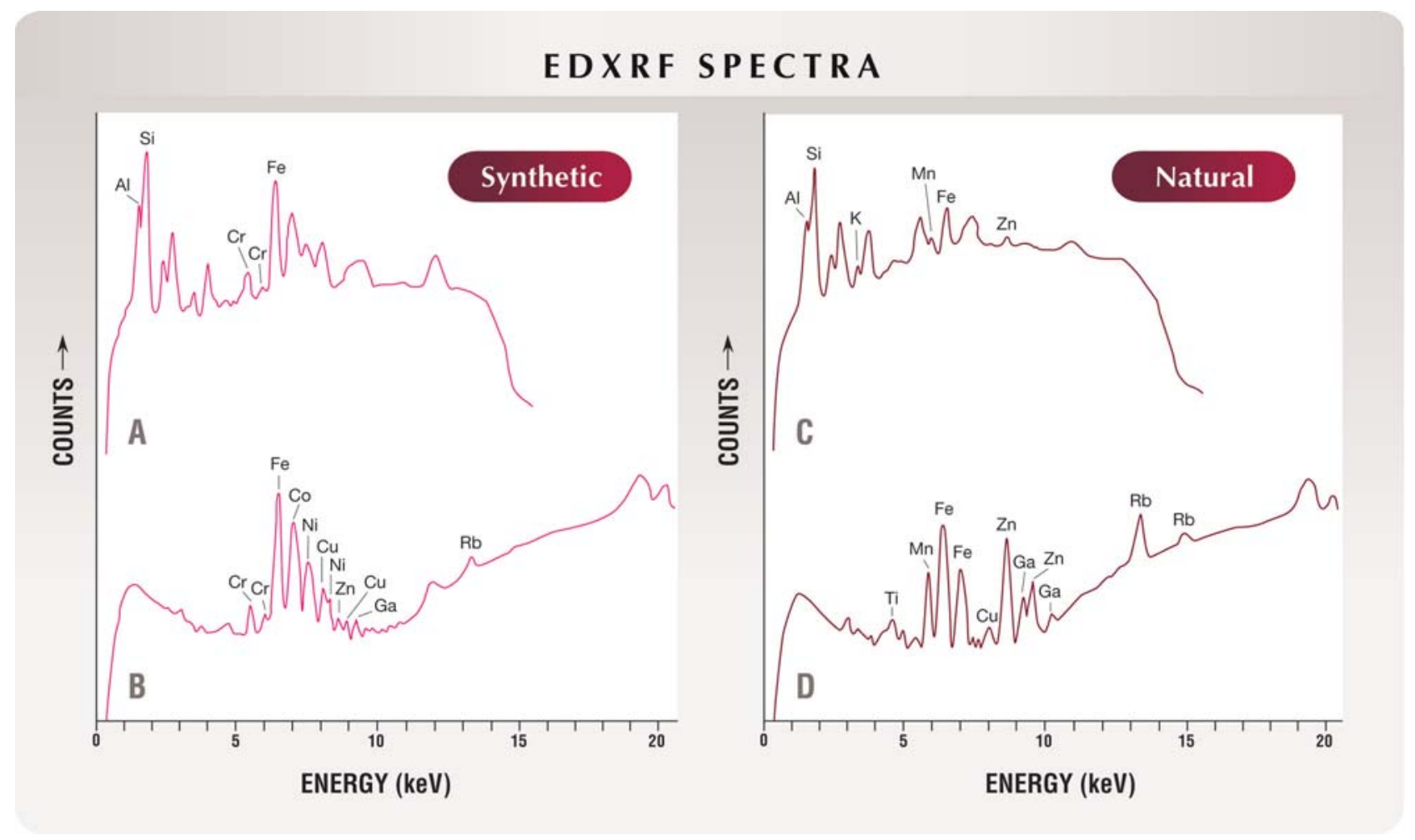




\section{VISIBLE SPECTRA}
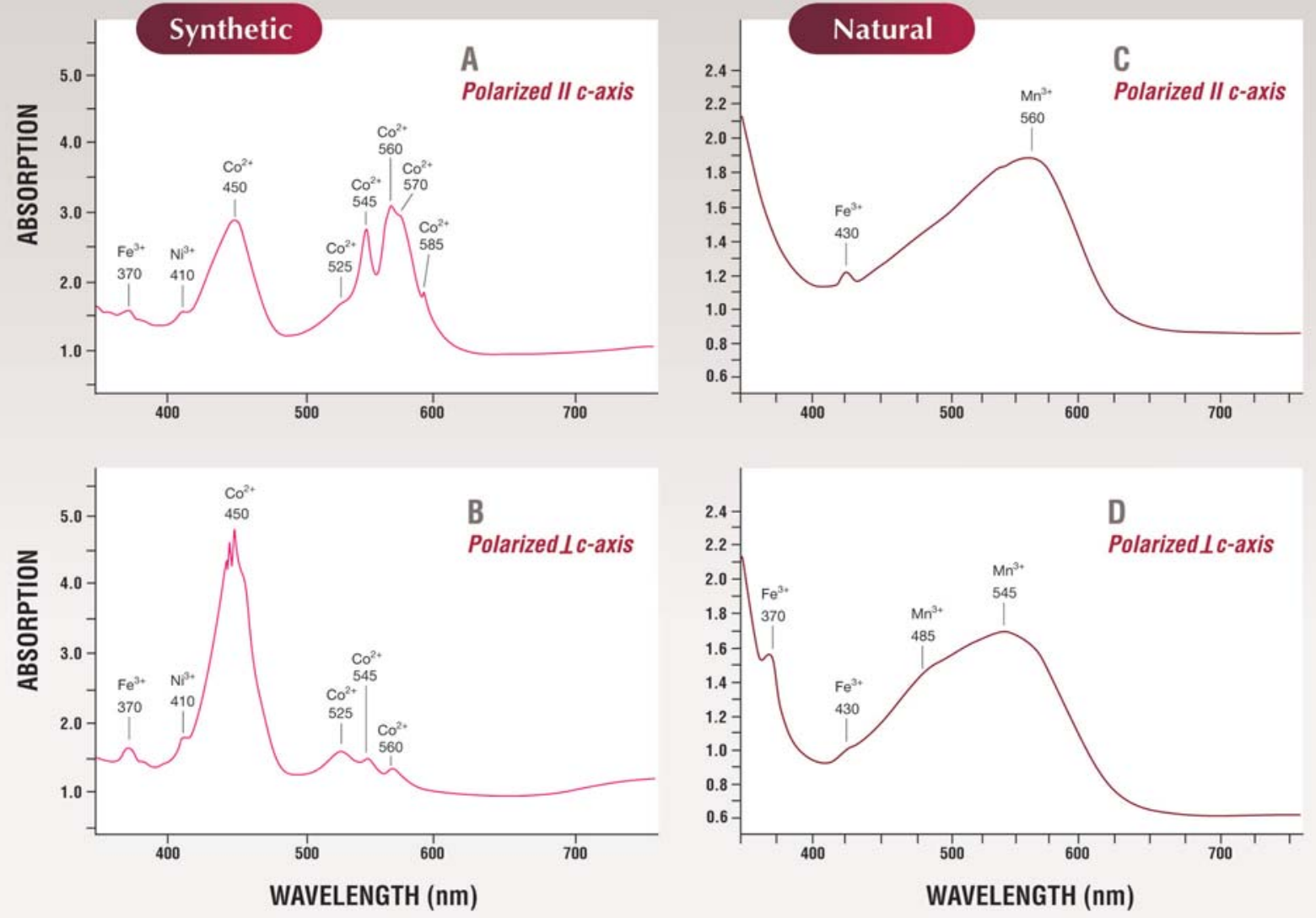

Figure 15. These polarized visible absorption spectra of synthetic ( $A$ and $B$ ) and natural ( $C$ and $D)$ red beryl reveal distinctive differences in the two materials. Note in particular the prominent Co-related absorption bands between about 530 and $590 \mathrm{~nm}$ in the synthetic material. Spectra A and B were recorded for a polished fragment $(2.7 \mathrm{~mm}$ thick) taken from an orange-red synthetic crystal. Spectra $C$ and D were recorded for an oriented natural purplish red crystal from Utah, on which a flat surface had been polished parallel to a prominent prism face (3.2 mm thick).

The spectrum polarized perpendicular to the caxis (figure 15D) displays a similar pattern, but with these additional features:

1. A weak band at about $370 \mathrm{~nm}\left(\mathrm{Fe}^{3+}\right)$

2. A weak band at about $485 \mathrm{~nm}\left(\mathrm{Mn}^{3+}\right)$ on the shoulder of the intense broad band that is mentioned above

3. An intense broad band that is centered at about $545 \mathrm{~nm}$

For either natural or synthetic red beryl, a visible spectrum recorded using unpolarized light will exhibit the more intense of these spectral features. In particular, the diagnostic series of $\mathrm{Co}^{2+}$ absorption bands would be present at approximately 530, 545, 560,570 , and $590 \mathrm{~nm}$ (due to $\mathrm{Co}^{2+}$ ) in the synthetic sample.
Infrared Spectroscopy. A comparison of midinfrared $\left(6000-400 \mathrm{~cm}^{-1}\right)$ spectra for representative natural and synthetic red beryls (figure 16) reveals absorption features that have been reported previously in hydrothermal synthetic beryls (see Schmetzer and Kiefert, 1990; Henn and Milisenda, 1999). The natural crystal displays almost no absorption features above $2300 \mathrm{~cm}^{-1}$, except for several weak features between about 3000 and $2800 \mathrm{~cm}^{-1}$. In contrast, the synthetic red beryl displays spectral features at about $5300 \mathrm{~cm}^{-1}$, a very strong region of absorption between 4200 and $3200 \mathrm{~cm}^{-1}$, and a series of weaker features from 3300 to $2300 \mathrm{~cm}^{-1}$. The absorption between 4200 and $3200 \mathrm{~cm}^{-1}$ has been attributed to the presence of water in beryl (Wood and Nassau, 1968; Aurisicchio et al., 1994). This latter feature in the spectrum of 


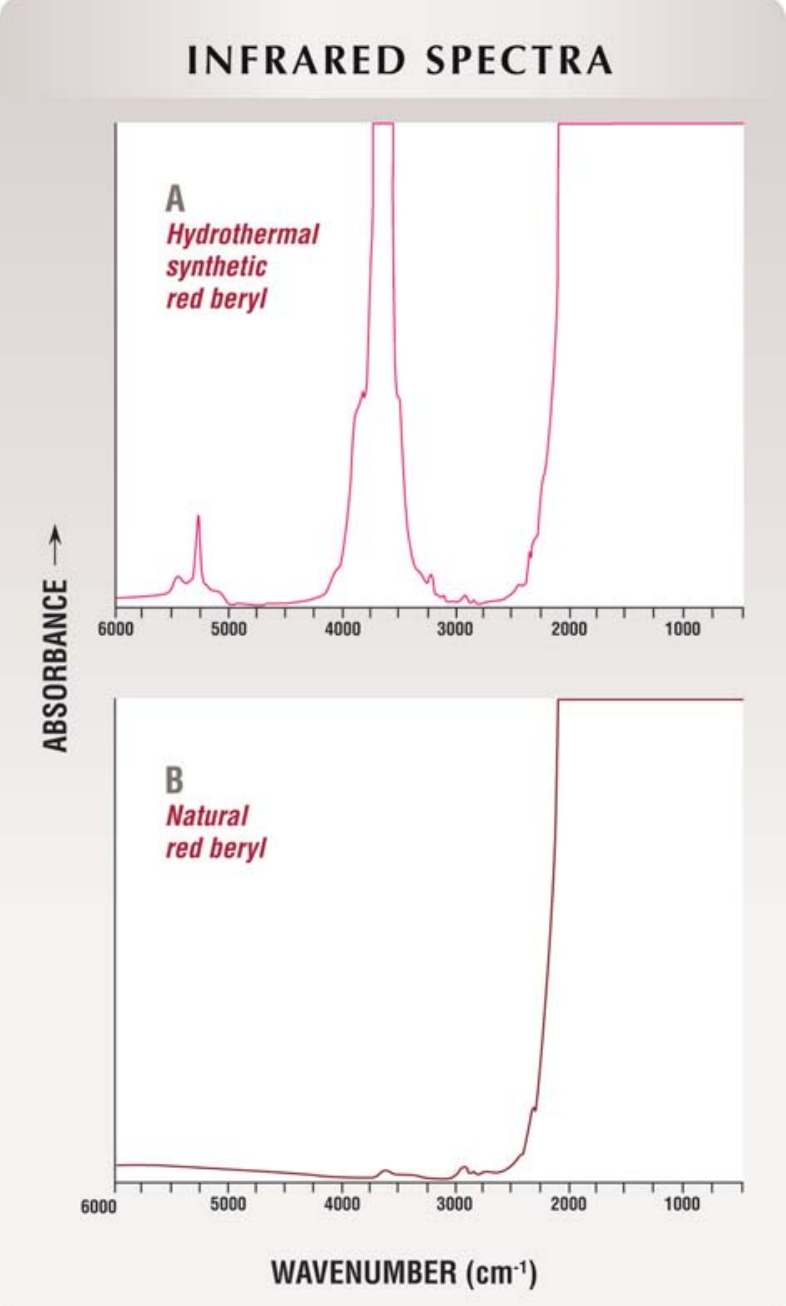

Figure 16. In these mid-infrared absorption spectra, strong absorption between 4200 and $3200 \mathrm{~cm}^{-1}$ is diagnostic of the synthetic red beryl (A). This absorption, which is due to water, is virtually absent in the spectrum of natural red beryl (B).

ABOUT THE AUTHORS

Dr.Shigley (jshigley@gia.edu) is director, Dr. Lu is research scientist, and Mr. Elen is supervisor of analytical equipment at GIA Research in Carlsbad, California. Mr. McClure is director of identification services, and Mr. Koivula is chief research gemologist at the GIA Gem Trade Laboratory in Carlsbad. Ms. Cole is collection curator at GIA in Carlsbad. Dr. Demianets is head of the Department of Crystal Growth from Solutions at the Institute of Crystallography, Russian Academy of Sciences, Moscow. She supervised the production of the synthetic red beryl described in this article. synthetic red beryl, and its absence in the spectrum of the natural counterpart (which contains very little water), is the most distinctive difference in infrared spectra, and it provides immediate proof that the material is a hydrothermal synthetic.

Schmetzer and Kiefert (1990) grouped natural and synthetic emeralds into five categories based on the relative intensities of the water-related midinfrared bands at 3694, 3592, and $3655 \mathrm{~cm}^{-1}$ (which they labeled as bands A, B, and C, respectively). The relative intensity ratio of these three bands in the synthetic red beryl is $\mathrm{A}>\mathrm{B}>>\mathrm{C}$. This result is consistent with the group II spectrum type, which Schmetzer and Kiefert (1990) suggested is typical of other low alkali-bearing synthetic beryls and synthetic emeralds grown in Russia.

\section{CONCLUSION}

Although natural red beryl remains a rare and relatively expensive gem material, its synthetic counterpart is also attractive but has not attained widespread demand. Synthetic red beryl has a distinctive tabular crystal morphology, chevron-like or wavy internal growth zoning, and several strong absorption bands between 530 and $590 \mathrm{~nm}$ due to coloration by $\mathrm{Co}^{2+}$. Overall, inclusions were rare in the synthetic red beryls examined for this study, but occasional single- or two-phase fluid (liquid or liquid-gas) and spicule inclusions were seen. In addition, the presence of $\mathrm{Co}$ and $\mathrm{Ni}$ is proof that the material is synthetic, as are water-related absorption bands between 4200 and $3200 \mathrm{~cm}^{-1}$ in the infrared spectra.

Acknowledgments: The authors thank Evgeni Vertkov of Worldwide Gem Marketing Corp., Huntington Beach, California. Sam Muhlmeister, a research associate at the GIA Gem Trade Laboratory (GTL), Carlsbad, helped with EDXRF analysis. Mike Moon, formerly of GIA Research, helped with collection of spectroscopic data. Dr. Chi Ma of the Division of Geological and Planetary Sciences, California Institute of Technology, Pasadena, carried out the electron microprobe analyses. Dr. Ilene Reinitz of the GIA GTL in New York provided helpful suggestions. The authors also thank Dr. Karl Schmetzer and two unidentified reviewers for their useful comments, and Kennecott Exploration Co. for the donation of two natural red beryl crystals analyzed as part of this study. 


\section{REFERENCES}

Aurisicchio C., Fioravanti G., Grubessi O., Zanazzi P.F. (1988) Reappraisal of the crystal chemistry of beryl. American Mineralogist, Vol. 73, No. 7/8, pp. 826-837.

Aurisicchio C., Fioravanti G., Grubessi O. (1990) Genesis and growth of the red beryl from Utah (U.S.A.). Atti Della Accademia Nazionale dei Lincei, Rendiconti Lincei, Scienze Fisiche e Naturali, Series 9, Vol. 1, No. 4, pp. 393-404.

Aurisicchio C., Grubessi O., Zecchini P. (1994) Infrared spectroscopy and crystal chemistry of the beryl group. Canadian Mineralogist, Vol. 32, Part 1, pp. 55-68.

Brown G. (1990) Biron synthetic pink beryl. Australian Gemmologist, Vol. 17, No. 6, pp. 219-221.

(1993) Australian titaniferous synthetic beryl. Journal of the Gemmological Association of Hong Kong, Vol. 16, pp. 5-6.

Bukin G.V., Godovikov A.A., Klaykhin V.A., Sobolev V.S. (1986) Growth of emerald single crystals. Growth of Crystals, Vol. 13 , pp. 251-260.

Černy' P., Hawthorne F.C. (1976) Refractive indices versus alkali contents in beryl: General limitations and applications to some pegmatitic types. Canadian Mineralogist, Vol. 14, Part 4, pp. 491-497.

Deer W.A., Howie R.A., Zussman J. (1997) Rock-forming Minerals, Vol. 1B, Disilicates and Ring Silicates. The Geological Society, London.

Demianets L.N. (1996) Regeneration growth of some hexagonal (trigonal) crystals under hydrothermal conditions. Collected Abstracts, International Union of Crystallography, 12th Congress and Assembly, Seattle, Washington, August 8-17.

Emel'yanova E.N., Grum-Grzhimailo S.V., Boksha O.N., Varina T.M. (1965) Artificial beryl containing V, Mn, Co, and Ni. Soviet Physics-Crystallography, Vol. 10, No. 1, pp. 46-49.

Flamini A., Gastaldi L., Grubessi O., Viticoli S. (1983) Sulle caratteristiche particolari del berillo rosso dell'Utah. La Gemmologia, Vol. 9, No. 1/2, pp. 12-20.

Fritsch E., Rossman G.R. (1987) An update on color in gems. Part 1: Introduction and colors caused by dispersed metal ions. Gems 4 Gemology, Vol. 23, No. 3, pp. 126-139.

Fritsch E., Muhlmeister S., Birkner A. (1992) A preliminary spectroscopic study of the Biron synthetic pink titanium-beryl. Australian Gemmologist, Vol. 18, No. 3, pp. 81-82.

Harding R.R. (1995) A note on red beryl. Journal of Gemmology, Vol. 24, No. 8, pp. 581-583.

Henn U., Becker G. (1995) Rote Berylle aus Utah, USA-Neue Beobachtungen. Zeitschrift der Deutschen Gemmologischen Gesellschaft, Vol. 44, No. 2/3, pp. 55-60.

Henn U., Milisenda C.C. (1999) Synthetische rote Berylle aus Russland. Gemmologie: Zeitschrift der Deutschen Gemmologischen Gesellschaft, Vol. 48, No. 2, pp. 97-104.

Hosaka M., Tubokawa K., Hatushika T., Yamashita H. (1993) Observations of red beryl crystals from the Wah Wah Mountains, Utah. Journal of Gemmology, Vol. 23, No. 7, pp. 409-411.

Lebedev A.S., Ilyin A.G., Klyakhin V.A. (1982) Hydrothermally grown beryls of gem quality. Morphology and Phase Equi- libria of Minerals, International Mineralogical Association, Meeting, Vol. 2, pp. 403-405 (in Russian).

(1983) Variétés de béryl "gemme" hydrothermal. Revue de Gemmologie a.f.g., No. 76, pp. 4-5.

Miley F. (1980) An examination of red beryl. Gems «) Gemology, Vol. 16, No. 12, pp. 405-408.

Nassau K. (1976) Synthetic emeralds: The confusing history and current technology. Journal of Crystal Growth, Vol. 35 pp. 211-222.

(1980) Gems Made by Man. Chilton Book Co., Radnor, PA.

Nassau K., Wood D.L. (1968) An examination of red beryl from Utah. American Mineralogist, Vol. 53, No. 5/6, pp. 801-806.

Platonov A.N., Taran M.N., Klyakhin V.A. (1989) On two colour types of $\mathrm{Mn}^{3+}$-bearing beryls. Zeitschrift der Deutschen Gemmologischen Gesellschaft, Vol. 38, No. 4, pp. 147-154.

Schaller W.T., Stevens R.E., Jahns R.H. (1962) An unusual beryl from Arizona. American Mineralogist, Vol. 47, No. 5/6, pp. 672-699.

Schmetzer K. (1988) Characterization of Russian hydrothermallygrown synthetic emeralds. Journal of Gemmology, Vol. 21, No. 3, pp. 145-164.

(1989) Types of water in natural and synthetic emerald. Neues Jahrbuch für Mineralogie Monatshefte, No. 1, pp. 15-26.

Schmetzer K., Kiefert L. (1990) Water in beryls-A contribution to the separability of natural and synthetic emeralds by infrared spectroscopy. Journal of Gemmology, Vol. 22, No. 4 pp. 215-223.

Schmetzer K., Bank H., Berdesinski W. (1974) Eine seltene rote Varietät der Mineralart Beryll. Zeitschrift der Deutschen Gemmologischen Gesellschaft, Vol. 23, No. 2, pp. 139-141.

Schmetzer K., Kiefert L., Bernhardt H.-J., Beili Z. (1997) Characterization of Chinese hydrothermal synthetic emerald. Gems e) Gemology, Vol. 33, No. 4, pp. 276-291.

Shigley J.E., Foord E.E. (1984) Gem-quality red beryl from the Wah Wah Mountains, Utah. Gems $\uplus$ Gemology, Vol. 20, No. 4, pp. 208-221.

Sinkankas J. (1981) Emerald and Other Beryls. Chilton Book Co. Radnor, PA.

Solntsev V.P., Kharchenko E.I., Lebedev A.S., Klyakhin V.A., Ilyin A.G. (1981) Nature of color centers and EPR of a manganese-activated beryl. Journal of Applied Spectroscopy, Vol. 34, No. 1, pp. 111-115.

Sosso F., Piacenza B. (1995) Russian hydrothermal synthetic emeralds: Characterization of the inclusions. Journal of Gemmology, Vol. 24, No. 7, pp. 501-507.

Taylor A.M. (1967) Synthetic cobalt beryl. Journal of Gemmology, Vol. 10, No. 8, pp. 258-261.

Troup G.T., Hutton D.R., Pilbrow J.R. (1990) Electron paramagnetic resonance and fluorescence of $\mathrm{Ti}^{3+}$ in Australian Biron synthetic beryl. In Abstracts, Australian Institute of Physics, 14th Condensed Matter Physics Meeting, Wagga Wagga, New South Wales.

Wood D.L., Nassau K. (1968) The characterization of beryl and emerald by visible and infrared absorption spectroscopy. American Mineralogist, Vol. 53, No. 5/6, pp. 777-800. 